\title{
Automated Synthesis of the Tumor-Associated Carbohydrate Antigens Gb-3 and Globo-H: Incorporation of $\alpha$-Galactosidic Linkages
}

\author{
Daniel B. Werz, Bastien Castagner, and Peter H. Seeberger* \\ Laboratory for Organic Chemistry, Swiss Federal Institute of Technology (ETH) Zürich, \\ HCI F 315, Wolfgang-Pauli-Str. 10, CH-8093 Zürich, Switzerland. \\ * To whom correspondence should be addressed: E-mail: seeberger@org.chem.ethz.ch
}

Supporting Information 
General Information. All chemicals used were reagent grade and used as supplied except where noted. Dichloromethane $\left(\mathrm{CH}_{2} \mathrm{Cl}_{2}\right)$ and tetrahydrofuran (THF) were purified by a Cycle-Tainer Solvent Delivery System. Flash column chromatography was carried out using forced flow of the indicated solvent on Fluka Kieselgel 60 (230-400 mesh). Preparative HPLC was performed using a Waters 1525 pump and Waters 2487 detector on a Waters Sunfire prep $\mathrm{C}_{8}$ reversed-phase column $(10 \times 150 \mathrm{~mm}) .{ }^{1} \mathrm{H}$ and ${ }^{13} \mathrm{C} \mathrm{NMR}$ spectra were recorded on a Varian VXR-300 (300 MHz) or Bruker DRX500 (500 MHz)

spectrometer. Mass spectra (MALDI MS) were performed by the MS service at the Laboratory for Organic Chemistry (ETH Zurich). ESI MS were run on an Agilent 1100 Series LC/MSD instrument. LCMS was performed on the same LC/MSD using a Waters Symmetry $\mathrm{C}_{18} 5 \mu \mathrm{m}(3.9 \times 150 \mathrm{~mm})$ reversed-phase column. The automated synthesis was performed on an $\mathrm{ABI} 431 \mathrm{~A}$ peptide synthesizer with a custom-made jacketed glass reaction vessel.

\section{Automated Modules:}

Module A: The resin is washed 6 times with THF for $15 \mathrm{sec}$. each.

Module B: The resin is washed 6 times with DCM for $15 \mathrm{sec}$. each.

Module D: The building block (5 eq., $0.125 \mathrm{mmol}$ in $1.5 \mathrm{~mL} \mathrm{DCM}$ ) is delivered to the reaction vessel containing the resin. The mixture is allowed to cool for $3 \mathrm{~min}$. (with vortex for $30 \mathrm{sec}$. followed by standing for $30 \mathrm{sec}$.). TMSOTf (5 eq., $0.125 \mathrm{mmol}$, in 
$1.0 \mathrm{~mL} \mathrm{DCM}$ ) is added to the reaction vessel with vortex in two portions, with $2 \mathrm{~min}$. interval. The reaction mixture is then left for $45 \mathrm{~min}$. (with vortex for $30 \mathrm{sec}$. followed by standing for $30 \mathrm{sec}$.). After that time, the solution is drained and the resin is washed once with DCM.

Module E: The resin is washed 6 times with DMF for 15 sec. each.

Module F: The resin is submitted to piperidine $(20 \% \mathrm{v} / \mathrm{v}$ in DMF, $2 \mathrm{~mL}$ ) for $5 \mathrm{~min}$. (with vortex for $30 \mathrm{sec}$., followed by standing for $30 \mathrm{sec}$.). After that time, the solution is drained and the resin is submitted to the same conditions twice.

Module G: The resin is washed 6 times with acetic acid ( $0.2 \mathrm{M}$ in THF) for $15 \mathrm{sec}$. each.

Module H: The building block (5 eq., $0.125 \mathrm{mmol}$ in $1.5 \mathrm{~mL} \mathrm{DCM}$ ) is delivered to the reaction vessel containing the resin. The mixture is allowed to cool for $3 \mathrm{~min}$. (with vortex for $30 \mathrm{sec}$., followed by standing for $30 \mathrm{sec}$.). TMSOTf ( 0.5 eq., $0.125 \mathrm{mmol}$, in $0.5 \mathrm{~mL} \mathrm{DCM}$ ) is added to the reaction vessel with vortex in one portion. The reaction mixture is then left for $60 \mathrm{~min}$. (with vortex for $30 \mathrm{sec}$. followed by standing for $30 \mathrm{sec}$.). After that time, the solution is drained and the resin is washed once with DCM.

Module I: The resin is washed with DCM for $15 \mathrm{sec}$. followed by hexanes. Reapeated 6 times. 
Module J: The building block ( 5 eq., $0.125 \mathrm{mmol}$ in $2 \mathrm{~mL} \mathrm{Et}_{2} \mathrm{O}$ ) is delivered to the reaction vessel containing the resin. The mixture is allowed to cool for $3 \mathrm{~min}$. (with vortex for $30 \mathrm{sec}$., followed by standing for $30 \mathrm{sec}$.). TMSOTf ( 5 eq., $0.125 \mathrm{mmol}$, in $1.0 \mathrm{~mL} \mathrm{DCM}$ ) is added to the reaction vessel with vortex in two portions, with $2 \mathrm{~min}$. interval. The reaction mixture is then left for $3 \mathrm{~h}$ (with vortex for $30 \mathrm{sec}$., followed by standing for $30 \mathrm{sec}$.). After that time, the solution is drained and the resin is washed once with DCM.

Module K: The building block (3.3 eq., $0.083 \mathrm{mmol}$ in $1.0 \mathrm{~mL} \mathrm{DCM}$ ) is delivered to the reaction vessel containing the resin. The mixture is allowed to cool for $1 \mathrm{~min}$. (with vortex for $30 \mathrm{sec}$., followed by standing for $30 \mathrm{sec}$.). TMSOTf ( 3.3 eq., $0.083 \mathrm{mmol}$, in $0.5 \mathrm{~mL} \mathrm{DCM}$ ) is added to the reaction vessel with vortex in one portions. The reaction mixture is then left for $25 \mathrm{~min}$. (with vortex for $30 \mathrm{sec}$., followed by standing for $30 \mathrm{sec}$.). After that time, the solution is drained and the resin is washed once with DCM.

Module L: The building block (5 eq., in $1.0 \mathrm{~mL}$ DCM) is delivered to the reaction vessel containing the resin. The mixture is allowed to cool for $1 \mathrm{~min}$. (with vortex for $30 \mathrm{sec}$., followed by standing for $30 \mathrm{sec}$.). TMSOTf $(0.25$ eq., in $0.25 \mathrm{~mL}$ DCM $)$ is added to the reaction vessel with vortex in one portions. The reaction mixture is then left for $25 \mathrm{~min}$. (with vortex for $30 \mathrm{sec}$., followed by standing for $30 \mathrm{sec}$.). After that time, the solution is drained and the resin is washed once with DCM. 


\section{$n$-Pentenyl $\quad 2,4,6$-Tri- $O$-benzyl- $\alpha$-D-galactopyranosyl-( $1 \rightarrow 4)$-3,6-di-O-benzyl-2- $O$ - pivaloyl- $\beta$-D-galactopyranosyl-( $1 \rightarrow 4)$-3,6-di- $O$-benzyl-2- $O$-pivaloyl- $\beta$-D-}

\section{glucopyranoside (4).}

Resin $14(0.35 \mathrm{mmol} / \mathrm{g}, 72 \mathrm{mg}, 0.025 \mathrm{mmol})$ was loaded in the reaction vessel of the synthesizer. Modules A, B, B were performed, then, the temperature was changed to -15 ${ }^{\circ} \mathrm{C}$ and modules $\mathrm{D}, \mathrm{B}, \mathrm{D}, \mathrm{B}$ were performed using building block $\mathbf{5}$. The temperature was raised to $20^{\circ} \mathrm{C}$ and modules $\mathrm{A}, \mathrm{E}, \mathrm{F}, \mathrm{E}, \mathrm{G}, \mathrm{A}, \mathrm{B}, \mathrm{B}, \mathrm{A}, \mathrm{B}, \mathrm{B}$ were performed. Fmoc quantification $^{1}$ of this first coupling indicated $17.7 \mu \mathrm{mol}$ of resin-bound monosaccharide. The temperature was changed to $-15^{\circ} \mathrm{C}$ and modules $\mathrm{D}, \mathrm{B}, \mathrm{D}, \mathrm{B}$ were performed using building block 6 . The temperature was raised to $20{ }^{\circ} \mathrm{C}$ and modules A, E, F, E, G, A, B, $\mathrm{B}, \mathrm{A}, \mathrm{B}, \mathrm{B}, \mathrm{A}, \mathrm{B}, \mathrm{B}, \mathrm{A}, \mathrm{B}, \mathrm{B}$ were performed. The temperature was changed to $-30^{\circ} \mathrm{C}$ and modules $\mathrm{H}, \mathrm{B}, \mathrm{H}, \mathrm{B}$ were performed using building block $\mathbf{1 2}$. The temperature was raised to $20{ }^{\circ} \mathrm{C}$ and modules $\mathrm{A}, \mathrm{E}, \mathrm{F}, \mathrm{E}, \mathrm{G}, \mathrm{A}, \mathrm{B}, \mathrm{B}$ were performed to give resin-bound trisaccharide $\mathbf{1 5}$. The resin was then charged in a $10 \mathrm{ml}$ round-bottomed flask and swelled with $2 \mathrm{~mL}$ DCM under Ar atmosphere. Grubbs' catalyst ( $1^{\text {st }}$ generation, $\left.2 \mathrm{mg}\right)$ was then added and the flask was put under ethylene atmosphere and stirred overnight. The resin was then washed $8 \times$ with DCM. The combined washes were treated with $\mathrm{Et}_{3} \mathrm{~N}$ (ca. 300 $\mu \mathrm{L})$ and $10 \mathrm{mg}$ tris(hydroxymethyl)phosphine for $30 \mathrm{~min}$. at room temperature. The organic layers were washed with saturated aq. $\mathrm{NaHCO}_{3}$ solution and extracted with DCM. The combined organic layers were dried with $\mathrm{Na}_{2} \mathrm{SO}_{4}$, concentrated under vacuum and quickly filtered through a pipet column with $3 \mathrm{~cm}$ silica, eluting with ethyl acetate. The eluted solution was concentrated under vacuum. The crude residue was then purified

\footnotetext{
${ }^{1}$ Love, K. R.; Seeberger, P. H. Angew. Chem. Int. Ed. 2004, 43, 602-605.
} 
by column chromatography (hexanes/ethyl acetate) followed by preparative HPLC using a gradient of 80 to $100 \%$ over $45 \mathrm{~min}$. of $\mathrm{MeCN} / i-\mathrm{PrOH}(4: 1)$ in $\mathrm{H}_{2} \mathrm{O} / i-\mathrm{PrOH}(4: 1)$. Yielded $11.2 \mathrm{mg}$ of $\alpha$-Gb3 4 (8.1 $\mu$ mol, 32\% yield from resin $\mathbf{1 4}$ or $46 \%$ based on Fmoc quantification of the first glycosylation): ${ }^{1} \mathrm{H}$ NMR $\left(600 \mathrm{MHz}, \mathrm{CDCl}_{3}\right)$ : 7.33-7.14 (m, $35 \mathrm{H}), 5.81-5.74(\mathrm{~m}, 1 \mathrm{H}), 5.25(\mathrm{dd}, J=10.4,7.4 \mathrm{~Hz}, 1 \mathrm{H}), 5.10(\mathrm{~d}, J=11.9 \mathrm{~Hz}, 1 \mathrm{H}), 5.01-$ $4.92(\mathrm{~m}, 4 \mathrm{H}), 4.77-4.72(\mathrm{~m}, 2 \mathrm{H}), 4.67-4.42(\mathrm{~m}, 8 \mathrm{H}), 4.36-4.32(\mathrm{~m}, 2 \mathrm{H}), 4.24-4.20(\mathrm{~m}$, 3H), 4.09-3.97 (m, 5H), 3.94-3.92 (m, 1H), 3.85-3.70 (m, 4H), $3.60(\mathrm{dd}, J=9.3,8.7 \mathrm{~Hz}$, $1 \mathrm{H}), 3.48-3.40(\mathrm{~m}, 3 \mathrm{H}), 3.39-3.30(\mathrm{~m}, 2 \mathrm{H}), 3.26(\mathrm{dd}, J=10.4,2.7 \mathrm{~Hz}, 1 \mathrm{H}), 3.07$ (dd, $J=$ 8.9, $5.0 \mathrm{~Hz}, 1 \mathrm{H}), 2.12-2.02(\mathrm{~m}, 2 \mathrm{H}), 1.75(\mathrm{~d}, J=5.7 \mathrm{~Hz}, 1 \mathrm{H}) 1.67-1.60(\mathrm{~m}, 2 \mathrm{H}), 1.15(\mathrm{~s}$, 9H), 1.10 (s, 9H). ${ }^{13} \mathrm{C}$ NMR (100 MHz, $\left.\mathrm{CDCl}_{3}\right): 176.7,176.6,139.2,138.9,138.6,138.3$, $138.3,138.2,138.1,138.0,128.4,128.4,128.3,128.2,128.1,128.1,128.1,128.0,127.9$, $127.7,127.7,127.7,127.6,127.5,127.5,127.4,114.8,101.3,100.1,99.9,81.2,79.9$, $77.5,75.3,75.2,74.4,74.4,73.5,73.5,73.2,73.0,72.9,72.3,71.7,71.2,70.0,68.9,68.9$, 68.3, 67.7, 67.6, 38.8, 38.7, 30.1, 28.8, 27.4, 27.1. ESI-LRMS: $m / z\left[\mathrm{M}+\mathrm{NH}_{4}\right]^{+}$calcd 1388.7, obsd 1388.6.

$n$-Pentenyl $\quad$ 2-O-Benzyl-3,4-di-O-pivaloyl- $\alpha$-L-fucopyranosyl-(1 $\rightarrow 2)-3,4,6$-tri- $O$ benzyl- $\beta$-D-galactopyranosyl-( $1 \rightarrow 3)-4,6-$ di- $O$-benzyl-2-deoxy-2- $N$ -

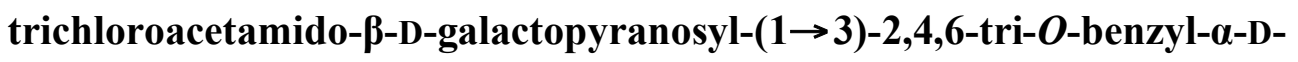
galactopyranosyl-( $1 \rightarrow 4)$-3,6-di- $O$-benzyl-2- $O$-pivaloyl- $\beta$-D-galactopyranosyl-( $1 \rightarrow 4)$ 3,6-di-O-benzyl-2- $O$-pivaloyl- $\beta$-D-glucopyranoside (3).

Resin $14(0.26 \mathrm{mmol} / \mathrm{g}, 92 \mathrm{mg}, 0.024 \mathrm{mmol})$ was loaded in the reaction vessel of the synthesizer. Modules A, I, B were performed and then the temperature was changed to 
$-15{ }^{\circ} \mathrm{C}$. Modules D, B, D, B were performed using building block 5 . The temperature was raised to $20{ }^{\circ} \mathrm{C}$ and modules $\mathrm{A}, \mathrm{E}, \mathrm{F}, \mathrm{E}, \mathrm{G}, \mathrm{A}, \mathrm{I}, \mathrm{B}, \mathrm{A}, \mathrm{I}, \mathrm{B}$ were performed. The temperature was changed to $-15{ }^{\circ} \mathrm{C}$ and modules $\mathrm{D}, \mathrm{B}, \mathrm{D}, \mathrm{B}$ were performed using building block 6 . The temperature was raised to $20{ }^{\circ} \mathrm{C}$ and modules A, E, F, E, G, A, I, B, A, I, B were performed. The temperature was changed to $-50{ }^{\circ} \mathrm{C}$ and modules $\mathrm{J}, \mathrm{B}, \mathrm{J}, \mathrm{B}$ were performed using building block $\mathbf{7 b}$. The temperature was raised to $20{ }^{\circ} \mathrm{C}$ and modules A, E, F, E, G, A, I, B, A, I, B were performed. The temperature was changed to $-15{ }^{\circ} \mathrm{C}$ and modules $\mathrm{K}, \mathrm{K}, \mathrm{K}, \mathrm{A}$ were performed using building block 8 . The temperature was raised to $20^{\circ} \mathrm{C}$ and modules $\mathrm{B}, \mathrm{A}, \mathrm{E}, \mathrm{F}, \mathrm{E}, \mathrm{G}, \mathrm{A}, \mathrm{I}, \mathrm{B}$ were performed to afford the resin-bound tetrasaccharide 16. The resin was dried under high vacuum. Half of the resin (12 $\mu \mathrm{mol})$ was reloaded in the reaction vessel. Modules A, I, B were performed, the temperature was then changed to $-10{ }^{\circ} \mathrm{C}$ and module $\mathrm{L}$, L, A were performed using building block 9 . The temperature was raised to $20{ }^{\circ} \mathrm{C}$ and modules A, E, F, E, G, A, I, B, A, I, B were performed. The temperature was changed to $-10{ }^{\circ} \mathrm{C}$ and modules $\mathrm{L}, \mathrm{L}, \mathrm{A}$ were performed using building block 10. The temperature was raised to $20{ }^{\circ} \mathrm{C}$ and modules A, B, A, I, B were performed to afford the resin-bound hexasaccharide. The resin was dried under high vacuum for $2 \mathrm{~h}$. The resin was then charged in a $10 \mathrm{ml}$ roundbottom flask and swelled with $2 \mathrm{~mL}$ DCM under Ar atmosphere. Grubbs' catalyst $\left(1^{\text {st }}\right.$ generation, $2 \mathrm{mg}$ ) was then added and the flask was put under ethylene atmosphere and stirred overnight. The resin was then washed $8 \times$ with DCM. The combined washes were quickly filtered through a pipet column with $3 \mathrm{~cm}$ of silica gel, eluting with ethyl acetate. The eluted solution was concentrated under vacuum. The crude residue was then purified by careful column chromatography (hexanes/ethyl acetate). Yielded $9.6 \mathrm{mg}$ of 
fully protected Globo-H hexasaccharide 3 (3.6 $\mu$ mol, 30\% yield from resin 14): ${ }^{1} \mathrm{H}$ NMR (500 MHz, $\left.\mathrm{CDCl}_{3}\right): 7.46(\mathrm{~d}, J=7.15 \mathrm{~Hz}, 1 \mathrm{H}), 7.28-7.04(\mathrm{~m}, 60 \mathrm{H}), 7.00-6.89(\mathrm{~m}, 5 \mathrm{H})$, 5.75-5.66 (m, 1H), $5.55(\mathrm{~d}, J=3.2 \mathrm{~Hz}, 1 \mathrm{H}), 5.42(\mathrm{dd}, J=10.7,2.9 \mathrm{~Hz}, 1 \mathrm{H}), 5.20(\mathrm{dd}, J=$ $10.2,7.9 \mathrm{~Hz}, 1 \mathrm{H}), 5.13-5.11(\mathrm{~m}, 1 \mathrm{H}), 5.05(\mathrm{~d}, J=2.2 \mathrm{~Hz}, 1 \mathrm{H}), 5.04(\mathrm{~s}, 1 \mathrm{H}), 4.95-4.75(\mathrm{~m}$, $7 \mathrm{H}), 4.69-3.82(\mathrm{~m}, 38 \mathrm{H}), 3.75-3.47(\mathrm{~m}, 10 \mathrm{H}), 3.40-3.26(\mathrm{~m}, 7 \mathrm{H}), 3.16-3.10(\mathrm{~m}, 2 \mathrm{H})$, 2.03-1.95 (m, 2H), 1.61-1.52 (m, 2H), 1.06 (s, 9H), $1.05(\mathrm{~s}, 9 \mathrm{H}), 1.01$ (s, 9H), $0.94(\mathrm{~s}$, 9H), $0.61(\mathrm{~d}, J=6.5 \mathrm{~Hz}, 3 \mathrm{H}) .{ }^{13} \mathrm{C} \mathrm{NMR}\left(125 \mathrm{MHz}, \mathrm{CDCl}_{3}\right): 178.5,177.3,177.0,176.7$, $162.8,140.1,139.4,139.3,139.3,139.1,138.9,138.7,138.6,138.4,138.3,138.3,138.3$, $129.0,128.9,128.9,128.8,128.8,128.7,128.6,128.6,128.6,128.5,128.5,128.4,128.4$, $128.3,128.2,128.1,128.1,128.0,128.0,127.9,127.9,127.8,127.8,127.7,127.6,127.5$, $127.4,127.3,115.2,102.8,101.6,101.2,100.9,100.1,97.0,84.2,80.7,78.6,78.2,76.7$, $76.6,75.8,75.7,75.5,75.0,74.9,74.8,74.7,74.5,74.5,74.3,74.0,73.9,73.8,73.5,73.4$, 73.3, 73.2, 73.1, 73.1, 72.4, 72.3, 72.0, 71.9, 71.6, 70.6, 69.4, 69.2, 69.1, 69.0, 68.8, 68.7, 68.4, 65.7, 39.3, 39.1, 39.1, 30.5, 29.3, 27.7, 27.7, 27.6, 27.5, 15.8. MALDI-LRMS: $\mathrm{m} / \mathrm{z}$ $[\mathrm{M}+\mathrm{Na}]^{+}$calcd 2715, obsd 2715 . 


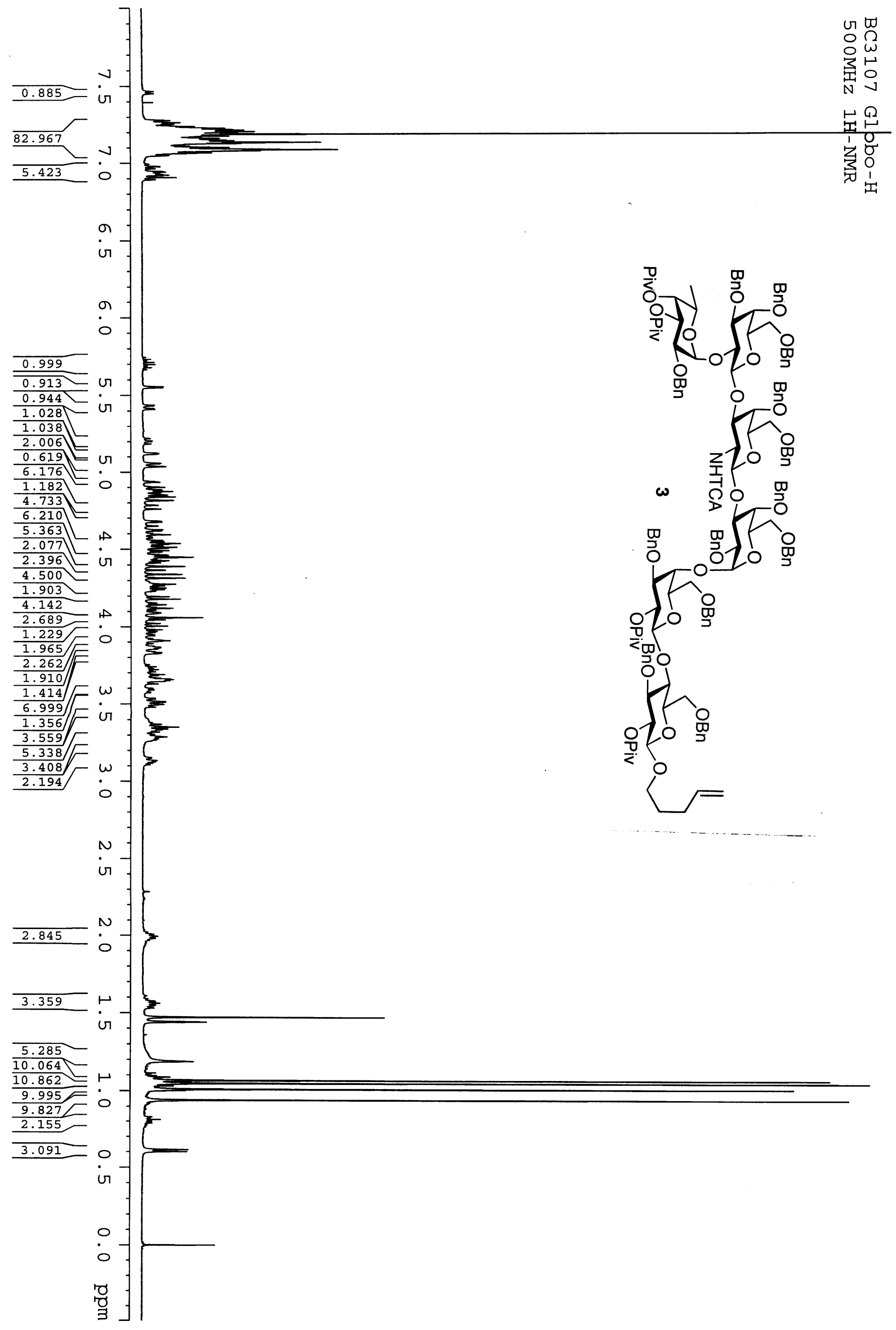




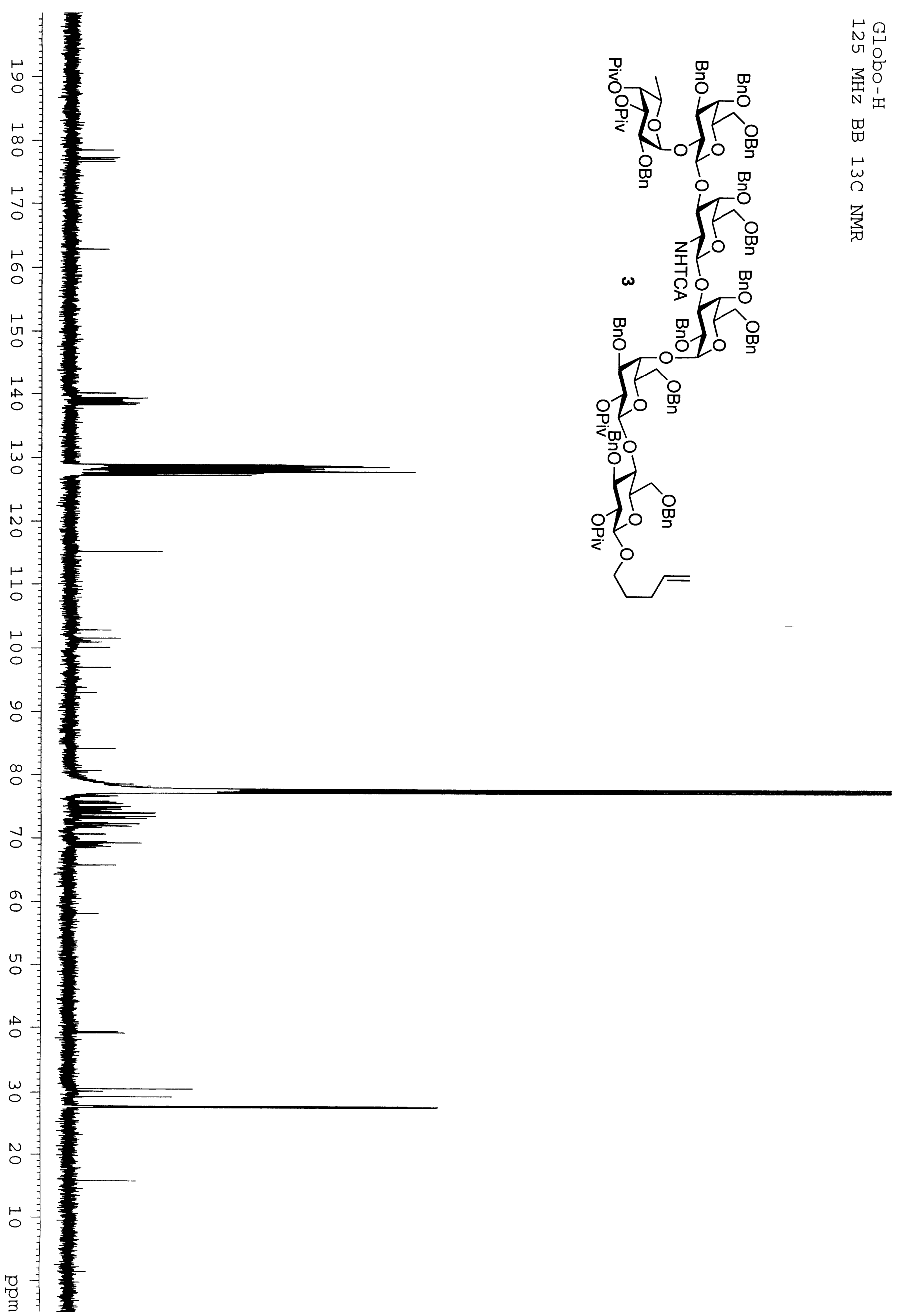




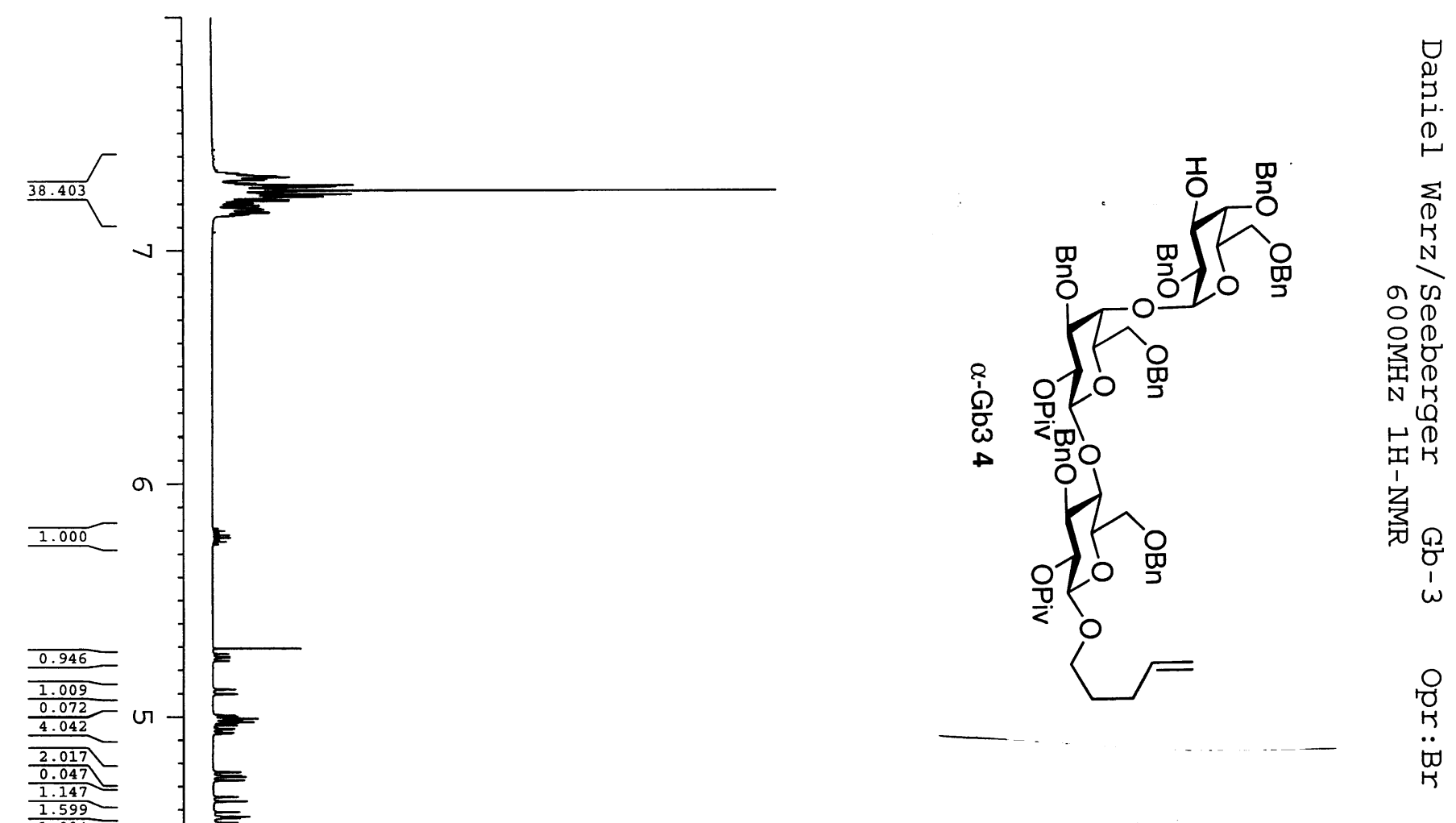



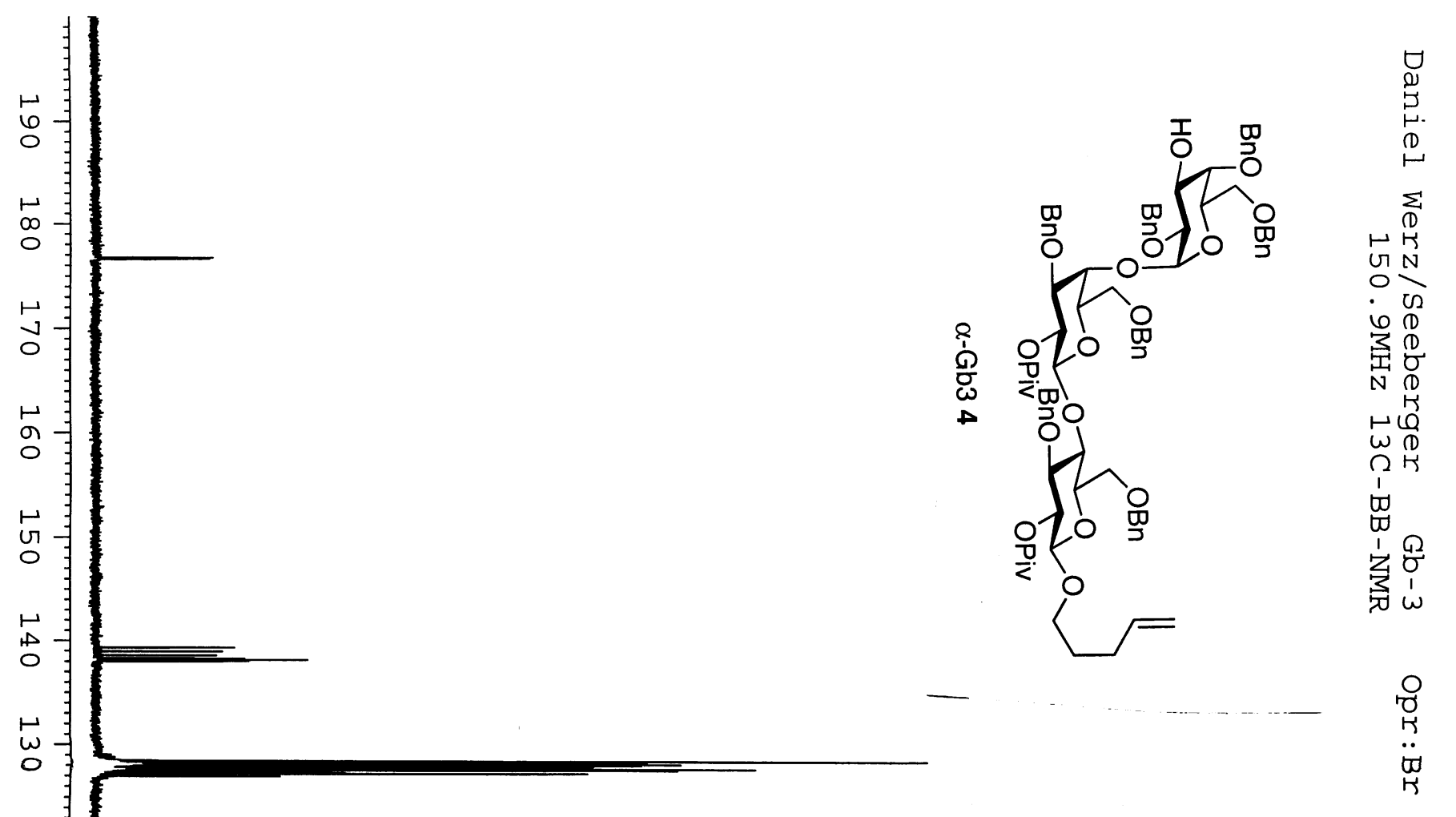

$\stackrel{\mapsto}{N}$

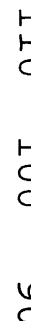

0

$\infty$

D

ㄱ.

a

G

U

$\stackrel{\leftrightarrow}{\circ}$

$\omega$

N

N

॰

骂四 